\title{
Additional Nest Structures and Natural Enemies of Stingless Bees (Hymenoptera: Apidae: Meliponinae)
}

\author{
NORITA WIDYA PANGESTIKA ${ }^{1}$, TRI ATMOWIDI ${ }^{2 *}$, SIH KAHONO ${ }^{3}$ \\ ${ }^{1}$ Student of Animal Bioscience Study Program, Graduate School, IPB University, Darmaga Bogor 16680 \\ ${ }^{2}$ Department of Biology, Faculty of Mathematics and Natural Sciences, IPB University, Bogor 16680 \\ ${ }^{3}$ Zoology Division (Museum Zoologicum Bogoriense), Research Center for Biology-LIPI, Cibinong 16912
}

Diterima 22 January 2018/Disetujui 3 March 2018

\begin{abstract}
Stingless bees (Hymenoptera: Apidae) are widely distributed in tropics and subtropics areas. Now these bees are farmed by the human because they produce honey and propolis. Natural enemies can disturb the colony that affects to nest structure and productivity of these bees. This study aimed to study the common nest structure and additional nest structure of stingless bees which caused by natural enemies. This research was conducted from August to November 2015. Samples were taken from three locations, i.e, Pasuruan (East Java), Tasikmalaya (West Java), and Rangkasbitung (Banten). Descriptive analysis was used to compare the structure and composition of the nest in bamboo and additional nest structures in relation with natural enemies. Generally, the structure and composition of the nest of stingless bees in bamboo consist of nest entrance, storage pots (honey and pollen), and brood cells. We didn't found natural enemies of stingless bees in Pasuruan and Tasikmalaya and these colonies did not create additional nest structures. In contrast, the colonies in Rangkasbitung created additional nest structures i.e. the inner entrance covered by batumen and cerumen and also build a root-like structure. Natural enemies found in the colony at Rangkasbitung were cockroaches (Blattodea: Blattidae), histerid beetles, Platysoma leconti (Coleoptera: Histeridae), nitidulid beetles, Carphophilus sp. (Coleoptera: Nitidulidae), and ants, Pheidole sp. (Hymenoptera: Formicidae).
\end{abstract}

Key words: stingless bees, nest structure, natural enemies, predator, parasite.

\section{INTRODUCTION}

Honey bees and stingless bees are classified in the family of Apidae. Their nests located in the cavities. However, the structure and the composition of their nests are different. Honey bee (genus Apis) has three types of nesting, i.e., cavitynesting with multi-combs (Apis mellifera and $A$. cerana), single comb nest outside by hanging or attached on the branch (Apis dorsata) and single comb nest on tree branches on dwarf honey bees (A. florea and A. andreniformis). Multi combs of cavity-nesting honeybees are built mainly by wax (Oldroyd and Wongsiri 2006).

Stingless bees have two types of nest i.e., cavity and base nests. Cavity nest is located on a trunk characterized by the outer entrance located on trunk hollows. This type of nests is usually located in a certain height. Base nest is usually located below or at the base of the tree characterized by outer entrance attached to the outer wall of the tree and is usually hidden (Nunes et al. 2011). These

*Penulis korespondensi:

E-mail: atmowidi@apps.ipb.ac.id bees often built their nest on termite and ants nests (Michener 1974). They generally build their nests in tree holes (Buchwald and Breed 2005) and also in wood, cracks in the walls or under the roof of residence (Kumar et al. 2012).

These stingless bees have local name i.e., teuweul (West Java), klanceng (Central Java), lanceng (East Java), galo-galo (Sumatera), and kelulut (Kalimantan). Stingless bees are found in the tropics and subtropics areas (Free 1993). They are also widely distributed in Indonesia i.e., 31 species in Kalimantan, 41 species in Sumatra, and 9 species in Java (Schwarz 1937). Sakagami et al. (1990) reported six species of stingless bees found in Java, those are Tetragonula laeviceps, Heterotrigona itama, T. drescheri, Tetrigona apicalis, Geniotrigona thoracica, and Lepidotrigona terminata. Genera of Homotrigona, Lepidotrigona, and Heterotrigona are endemic for the tropics and subtropics areas in Asia (Michener 2000).

The stingless bees can be found in the forests, some types can also be adaptable in open forest areas, grasslands, and there is also in the settlement (Inoue et al. 1985). Some of these species also build nests underground (Jalil and Shuib 2014). Nest of 
stingless bees is constructed mainly by resin. The arrangement of the cells in the nest of stingless bees consists of cluster and comb (Michener 1974). Nest is an artificial construction used by bees to lay eggs, spend time, and nurture of young bees. The nest of stingless bees consists of entrance, cerumen, batumen, involucrum, storage pots, and brood cells. Cerumen is a mixture of propolis (resin) and wax to construct storage pots and brood cells. Batumen consists of resin or wax as a layer of cavity nest (Jalil and Shuib 2014). Batumen and cerumen are used to protect the inner part of the hive. Involucrum is a layer around brood cells (Michener 2007).

Stingless bees are social insects that have an important role as plants pollinators (Wille 1983; Inoue et al. 1985) and have high economic value related their ability to produce honey and propolis. Honey of stingless bees has a distinctive scent with a lemon fragrance-like taste characterized by the mixture of sweet and sour flavour, compared to the honey produced by honey bees. The honey of stingless bees has darker color, more acidic taste and contains higher phenolic compounds (Garedew et al. 2003; Kek et al. 2014). Propolis possesses anti-bacterial, anti-microbial, and anti-fungal properties (Sforcin and Bankova 2010). Stingless bees produce high propolis compared to honey bees (Fatoni 2008). However, natural enemies like predators and parasites can reduce the productivity of bees, disturb the colony, as well as affect the structure and composition of the nest or even kill the individual of bees.

Predators are animals that prey on other animals (Estes et al. 2001). Some predators attack the colony of stingless bees, i.e. wasps, ants, spiders, and centipedes. Centipedes may damage bee colonies within 2-5 seconds because they have a morphological variation and adaptation to take, catch, and hold prey (Kumar et al. 2012). Suicide bite is usually done by the bees as a defense mechanism against predators (Shackleton et al. 2015). Parasites are organisms that live on other organisms. The parasites commonly found in honey bees are mites, fleas, moths, and small beetles (Strauss et al. 2013). These parasites can be harmful to the health of honey bees (Shen et al. 2005). Natural enemies like predators and parasites on the stingless bees have not been widely reported yet. So that these research are really important to conduct. The research aimed to study the natural enemies of stingless bees and additional nest structure related to natural enemies.

\section{MATERIALS AND METHODS}

Sample Collections. Collection of stingless bee colonies were taken from August to November
2015. Ten colonies were taken from Pasuruan (East Java), eleven colonies from Tasikmalaya (West Java), and nineteen colonies from Rangkasbitung (Banten province).

Observation of Nest Structure of Stingless Bees. Each colony of stingless bees was observed and classified based on their caste systems. The structure and composition of the nest were observed i.e., the outer entrance, inner entrance, storage pots (honey and pollen), and brood cells. Each colony observed then was moved to wood box, sized $30 \mathrm{x}$ $25 \times 15 \mathrm{~cm}$.

Identification of Stingless Bees and Natural Enemies. Description of samples of stingless bees collected from each area were conducted based on morphological study. Identification of stingless bees based on Sakagami (1990) and Michener (2007). Natural enemies studied were collected from the stingless bees in bamboo. Afterward, both samples, stingless bees and their natural enemies were preserved in $70 \%$ ethanol. Samples were identified in the Laboratory of Entomology, Indonesian Institute of Sciences (LIPI) at Cibinong, Bogor.

Data Analysis. The species of stingless bees and natural enemies collected from each area were described. Nest structure and additional nest structure arised by natural enemies of stingless bees also were described.

\section{RESULTS}

A total of 39 colonies of stingless bees were identified as Tetragonula sp. The species is a small genus (about $3.5 \mathrm{~mm}$ body length) with a brownblackish body and transparent wings. A total of 39 colonies found, $64 \%$ colonies have the common nest structure and the remaining (36\%) with the additional nest structure (Table 1).

Stingless bee colonies of Pasuruan and Tasikmalaya did not create the additional nest structure. Contrary, more colony of Rangkasbitung created additional nest structure $(73.68 \%)$ and the remaining have common nest-structure $(26.32 \%)$ (Figure 1). Observation in the fields showed that natural enemies were not found in colonies of Pasuruan and Tasikmalaya. In contrast, more colonies of Rangkasbitung (52.63\%) in bamboo attacked by natural enemies (Table 2).

The Common Nests-Structure of Stingless Bees. Commonly, nest structure of stingless bees in bamboo, from outer to inner are nest entrance, cerumen, storage pots, brood cells, and cerumen (Figure 2). Nest entrance is a tunnel for leaving and returning of the colony members. Storage pots consist of honey and pollen pots that are used by colony as nutrient sources. Brood cells have a 
Table 1. Common nest-structure and additional nest-structure of stingless bees species from each sampling area

\begin{tabular}{lcc}
\hline \multirow{2}{*}{ Location of colony } & \multicolumn{2}{c}{ Nest structure } \\
\cline { 2 - 3 } & Common & Additional \\
\hline Pasuruan & 10 & - \\
Tasikmalaya & 10 & - \\
Rangkasbitung & 5 & 9 \\
\hline Total & 25 & 14 \\
\hline Percentage (\%) & 64 & 36
\end{tabular}

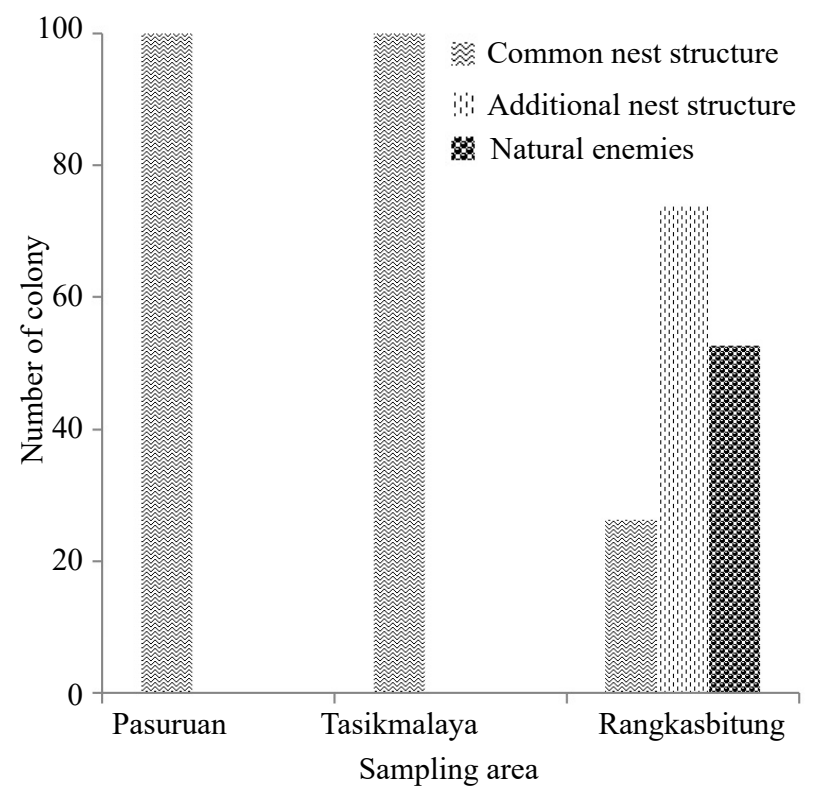

Figure 1. Percentage of common nest structure, additional nest structure, and natural enemies in study sites

smaller size than storage pots that are used by queen to lay eggs.

The Additional Nest Structures of Stingless Bees. Colonies of Rangkasbitung created the additional nest structure, when their nest is damaged or attacked by natural enemies, such as predators and parasites. Results showed that some additional nest structure were inner entrance with much batumen and cerumen and also create the root-like structure (Figure 3).

Natural Enemies of Stingless Bees. Ten colonies in bamboos at Pasuruan and 10 colonies at Tasikmalaya were found without their natural enemies. However, 10 colonies at Rangkasbitung were found with their natural enemies, such as cockroaches (Blattodea: Blattidae), Platysoma leconti (Coleoptera: Histeridae), Carpophilus sp. (Coleoptera: Nitidulidae). We also found several eggs of lizard on the nest and larva of termites at outer layer of bamboo (Table 2, Figure 4).

\section{DISCUSSION}

Nests Structure of Stingless Bees. Results showed that the nest structure and composition of stingless bees in bamboo, from the outside to the
Table 2. A number of stingless bee colonies were attacked by natural enemies

\begin{tabular}{lccc}
\hline Natural enemies & \multicolumn{3}{c}{ The number of colonies attacked } \\
\cline { 2 - 4 } & $\begin{array}{c}\text { Pasuruan } \\
(\mathrm{n}=10)\end{array}$ & $\begin{array}{c}\text { Tasikmalaya } \\
(\mathrm{n}=10)\end{array}$ & $\begin{array}{c}\text { Rangkasbitung } \\
(\mathrm{n}=19)\end{array}$ \\
\hline $\begin{array}{l}\text { Platysoma leconti } \\
\text { (Coleoptera: }\end{array}$ & - & - & 6 \\
$\begin{array}{l}\text { Histeridae) } \\
\text { Carpophilus } \\
\text { sp. (Coleoptera: }\end{array}$ & - & - & 2 \\
$\begin{array}{l}\text { Nitidulidae) } \\
\text { Cockroaches }\end{array}$ & - & - & \\
$\begin{array}{l}\text { (Blattodea: } \\
\text { Blattidea) }\end{array}$ & & & \\
\hline Total & - & - & \\
\hline Percentage $(\%)$ & - & - & 52.63 \\
\hline
\end{tabular}

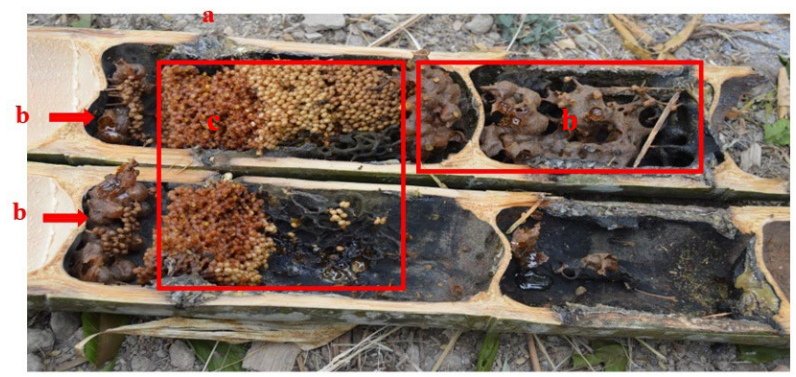

Figure 2. Structure and composition of the cavity-nesting of stingless bees in bamboo: (a) the nest entrance, (b) storage pots, (c) brood cells

inside, consist of nest entrance, cerumen, storage pots (honey and pollen), brood cells, and storage pots. Generally, the structure and composition of stingless bee nests consist of nest entrance, inner tunnel, brood cells, storage pots (honey and pollen), and batumen layers (Sakagami et al. 1983).

The nests are generally built by materials, such as wax, resin, and mud. Wille (1983) stated that bees used olfactory cues to locate the resin and food sources (nectar and pollen). Lack of plant resins causes a pot of food storage and brood cells are transparent (Leonhardt et al. 2010). Cerumen is a resin material mixed with wax. The wax of the stingless bee has a higher melting point compared to the wax of honey bees (A. mellifera) (Blomquist et al. 1985). In a higher concentration of the wax than resin, the texture of the nest becomes harder. The waxy nest can furthermore be hardened by mud to make batumen. While involucrum is cerumen located at around the brood cells to protect the nest from predators and parasites (Michener 2007).

There are two types of brood cells, cluster and comb. Brood cells without eggs have darker in color, whereas those containing eggs are transparent. Chinh et al. (2005) stated the new cells were yellowbrownish in color but after the wax eroded to be transparent. Cells are connected with another cell by pillars. Leonhardt et al. (2010) showed brood cells associated with one pillar with a small ball 

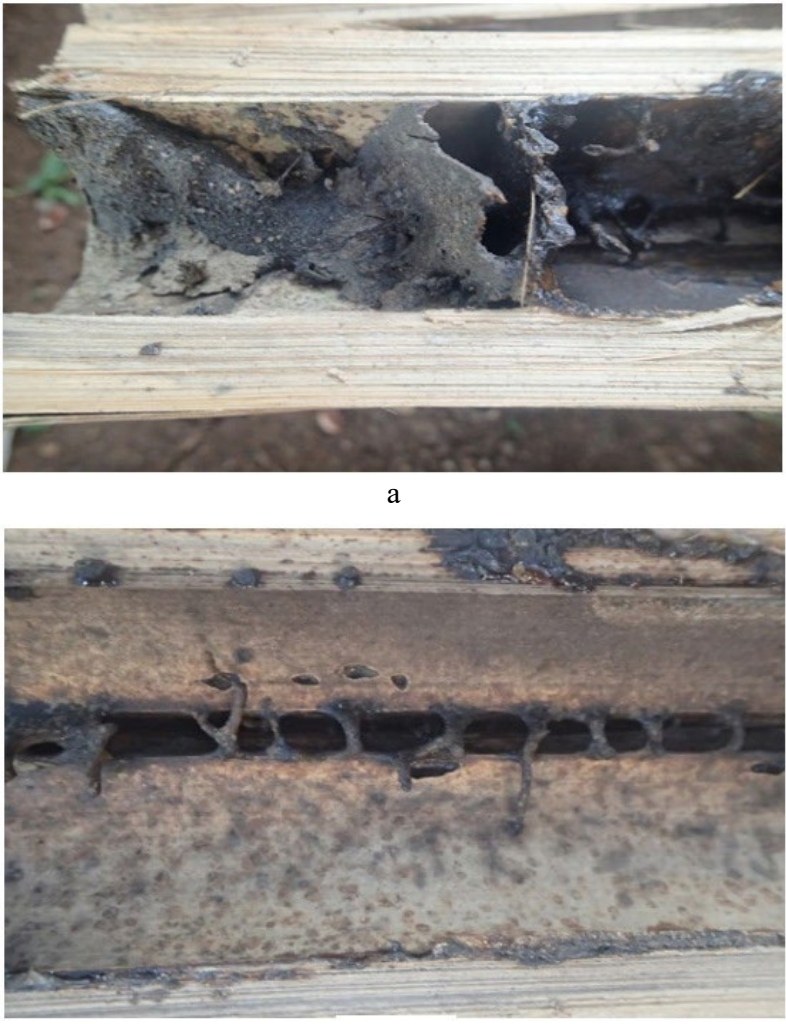

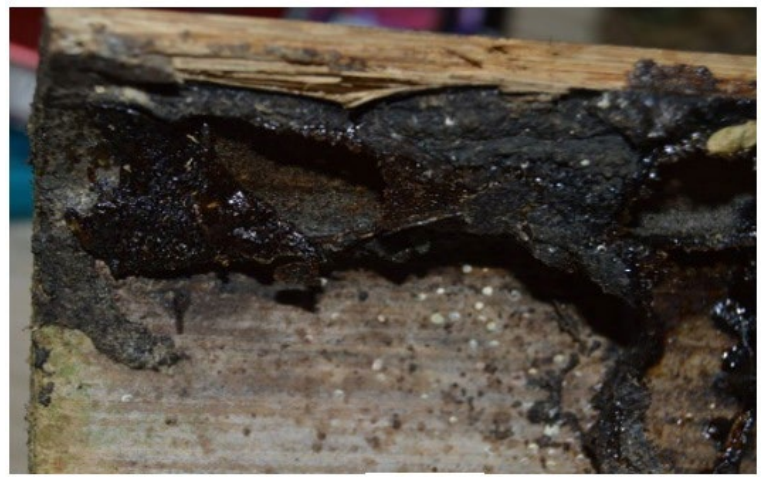

b

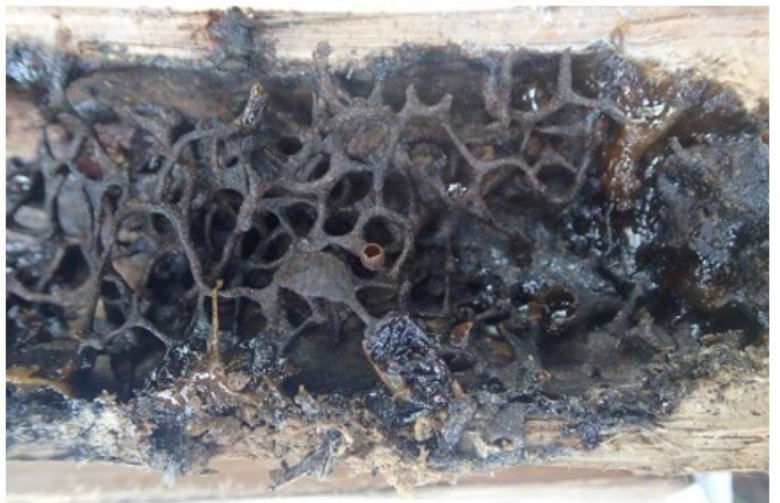

d

Figure 3. Nest structure of stingless bee: (a) the additional nest structure, the inner entrance with batumen, (b) the inner entrance with cerumen, (c) nest with batumen, (d) and root-like structure

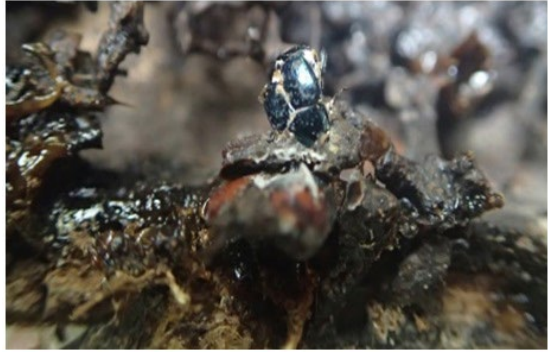

a
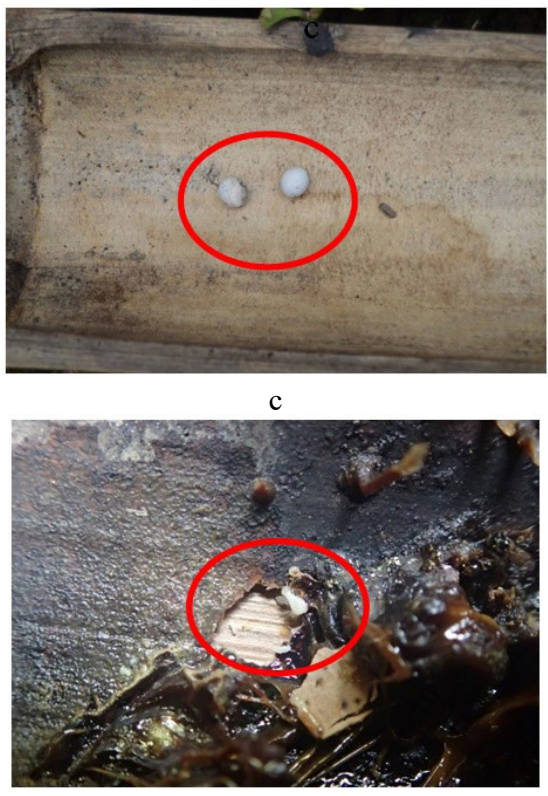

e
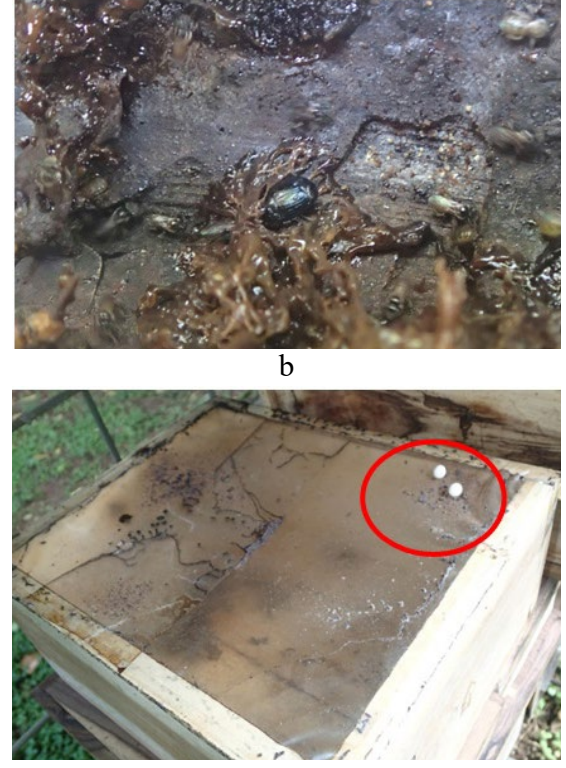

d

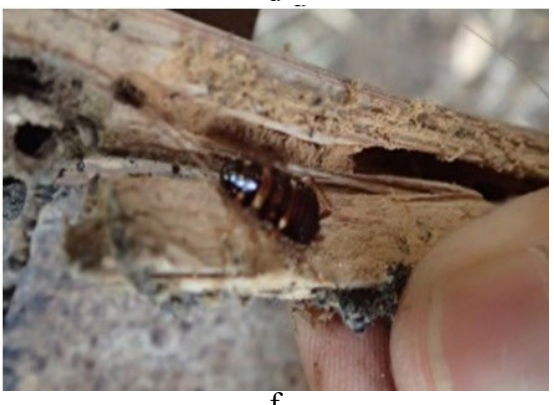

Figure 4. Natural enemies attacked the stingless bee colonies in bamboo: (a) Platysoma leconti (mummified), (b) P. leconti stuck in sticky cerumen, (c) eggs of lizard on bamboo colony, (d) eggs of lizard on plastic cover of wooden box, (e) and larva of termites at bamboo, (f) and the cockroach 
shape. Additional nest structures were found on the bamboo colony in Rangkasbitung, Banten Province. This structure is built in rotted cavities to protect the colony from predators and parasites. Roubik (2006) reported that these bees build the architecture in the inside of the hive to protect from natural enemies. In addition, the colonies use a lot of wax to avoid predators and parasites. Chinh et al. (2005) reported that the inner surface of a nest is usually decorated with black cerumen with a thickness of 1.5-2.0 mm.

Natural Enemies of Stingless Bees. Natural enemies were not found in colonies of Tasikmalaya (West Java) and Pasuruan (East Java). Contrary, some predators, such as cockroaches (Blattidae), histerid beetles (Platysoma leconti), and nitidulids beetles (Carphophilus sp.) were found in the colony of Rangkasbitung. Some of the lizard eggs also were found in the bamboo or box colonies. Ants (Pheidole sp.) were found in the stingless bee colonies that moved to wood box. In India, Kumar et al. (2012) reported some predators attacked the colony of stingless bees, including wasps, ants, spiders, and centipedes. Ants are predator, in high number of individuals, it can interfere the colony of stingless bees.

The resin is used as a defense mechanism against natural enemies (Roubik 2006; Leonhardt et al. 2010). Defense mechanism against predators also was showed by workers of the stingless bee by standing and hovering. Standing is the behavior of worker bees which keep the entrance of the hive. While, hovering is the behavior of worker bees which fly near the entrance of the nest. In the evening, some species of stingless bees close the outer entrance by wax with a thickness of $<0.05 \mathrm{~mm}$ (Gruter et al. 2010). If the colonies were disturbed by humans, workers showed defense behavior, like biting and attacking the hair, eyes, nose, and ears (Wille 1983).

Additional Nest Structures of Stingless Bees Arose as a Results of Natural Enemies. The shape of the nest entrance of stingless bees varied. These colonies built nest entrance surrounded by cerumen. Chinh et al. (2005) reported the shape of the nest entrance and inner entrance usually are not found in T. laeviceps. Nest entrance is usually found at the tree cavity an average height of $90 \mathrm{~cm}$ above the ground and or in artificial contruction of human (Sakagami et al. 1983).

The nests structure of stingless bees has two main parts i.e., storage pots and brood cells. Storage pots are usually distubuted at near of nest entrance and at behind the brood cells, round in form, thin walls, and dark brown in color. The thickness of storage pots is less than $1 \mathrm{~mm}$. Brood cells have the smaller than storage pots (Chinh et al. 2005). Brood cells initially open and closed after the egg is laid. Commonly, brood cells arranged regularly in the horizontal combs and pollen pots are commonly found near the brood cells. Brood cells contain nutrient for the development of eggs and larvae, such as pollen, nectar, and honey (Michener 2000).

Additional nest structures is built to defend against predators. Several predators found in this study were cockroaches (Blattodea: Blattidae), histerid beetles Platysoma leconti (Coleoptera: Histeridae), nitidulid beetles Carphophilus sp. (Coleoptera: Nitidulidae) and ants Pheidole sp. (Hymenoptera: Formicidae). The beetle larvae live in colonies of bees to obtain nutrient sources. Whereas, ants in the bee colonies aim to taking a food. Chinh et al. (2005) reported that worker bees defend their colony against ants by biting and using a resin to block the outer and inner entrance of the nest.

\section{CONCLUSION}

The common nest structure of stingless bees in bamboo are nest entrance, cerumen, storage pots, brood cells, and storage pots. Nest of an underground colony of stingless bees is round-shape and brood cells are covered by storage pots and involucrum. The additional nest structure is contructed by batumen, consists of inner entrance lined by batumen or cerumen with a certain thickness, and nest with a roots-like structure to trap the predators and parasites. Predators attacked the colonies of stingless bees in Rangkasbitung were cockroaches (Blattidae), histerid beetles (Platysoma leconti), nitidulid beetles (Carpophilus sp.), and ants (Pheidole sp.).

\section{ACKNOWLEDGEMENTS}

We thank to Biovilage Project of Indonesian Institute of Sciences, Indonesia endowment fund for education (LPDP) of Ministry of Finance. We also thanks to staff of Biology Department of IPB University and staff of Zoology of Indonesian Institute of Sciences (LIPI) for permission and use facilities during the research.

\section{REFERENCES}

Blomquist GJ et al. 1985. Wax chemistry of two stingless bees of the trigonisca group (Apidae: Meliponinae). Comp Biochem Physiol 82:137-142.

Buchwald R, Breed MD. 2005. Nestmate recognition cues in a stingless bee, Trigona fulviventris. Anim Behav 70:13311337.

Chinh TX et al. 2005. Nest architecture and colony characteristic of three stingless bees in North Vietnam with the first description of the nest of Lisotrigona carpenter Engel (Hymenoptera: Apidae, Meliponini). J Kans Entomol Soc 3:26-39. 
Estes J et al. 2001. Predators, ecological role of. Encyclopedia of Biodiversity 4:857-878.

Fatoni A. 2008. Pengaruh propolis Trigona spp. asal Bukit Tinggi terhadap beberapa bakteri usus halus sapi dan penelusuran komponen aktifnya [Tesis]. Bogor: Institut Pertanian Bogor.

Free JB. 1993. Insect Pollination of Crops. Cambridge: Academic Press.

Garedew A et al. 2003. The antimicrobial activity of honey of the stingless bee Trigona spp. Journal of Apicultural Science 47:37-49.

Gruter C et al. 2010. The natural history of nest defence in a stingless bee, Tetragonisca angustula (Latreille) (Hymenoptera: Apidae) with two distinct types of entrance guards. Neotropical Entomology 40:55-61.

Inoue T et al. 1985. Foraging behavior of individual workers and foraging dynamics of colonies of three Sumatran stingless bees. Res Popul Ecol 27:373-392.

Jalil AB, Shuib I. 2014. Beescape for Meliponines. Singapore: Partridge Publishing.

Kek SP et al. 2014. Total phenolic contents and colour intensity of Malaysian honeys from the Apis spp. and Trigona spp. bees. Agriculture and Agricutural Science Procedia 2:150-155

Kumar MS et al. 2012. Traditional beekeeping of stingless bee (Trigona sp.) by Kani tribes of Western Ghats, Tamil Nadu, India. Indian Journal of Tradional Knowledge. 11:342-345.

Leonhardt SD. 2010. Stingless bees use Terpenes as olfactory cues to find resin sources. Chem Senses 35:603-611.

Michener CD. 1974. The Social Behavior of the Bees. Cambrigde: Harvard University Press.

Michener CD. 2000. The Bees of the World. 1 ed. Maryland: JHU Press.
Michener CD. 2007. The Bees of the World. 2 ed. Maryland: JHU Press.

Nunes TM et al. 2011. Nestmate recognition in the stingless bee Frieseomelitta Varia (Hymenoptera, Apidae, Meliponini): sources of chemical signals. Animal Behaviour 81:463467.

Oldroyd BP, Wongsiri S. 2006. Asian Honey Bees. Cambridge: Harvard University Press.

Roubik DW. 2006. Stingless bee nesting biology. Apidologie 37:124-143.

Sakagami SF. 1983. Nest architecture and colony composition of the Sumatran stingless bee Trigona (Tetragonula) laeviceps Kontyu Tokyo 51:100-114.

Sakagami SF et al. 1990. Natural History of Social Wasps and Bees in Equatorial Sumatra. Sapporo: Hokkaido University Press.

Schwarz HF. 1937. The Indo-Malayan Species of Trigona. Bull Am Mus Nat Hist 76:83-141.

Sforcin JM, Bankova V. 2010. Propolis: is there a potential for the development of new drugs. Journal of Ethnopharmacology 133:253-260.

Shackleton K et al. 2015. Appetite for self-destruction: suicidal biting as a nest defense strategy in Trigona Stingless bees. Behav Ecol Sociobiol 69:273-281.

Shen M et al. 2005. Intricate transmission routes and interactions between picorna-like viruses (kashmir bee virus and sacbrood virus) with the honeybee host and the parasitic varroa mite. Journal of General Virology 86:2281-2289.

Strauss U et al. 2013. Seasonal prevalence of pathogens and parasites in the savannah honeybee (Apis mellifera scutellata). Journal of Invertebrate Pathology 114:45-52.

Wille A. 1983. Biology of the stingless bees. Annual Review of Entomology 28:41-64. 